Book Review

Historisitas dan Signifikansi Kitab Manāqib Shaykh 'Abd al-Qōdir al-Jìlānī dalam Historiografi Islam by Ajid Thohir (Jakarta: Kementerian Agama RI Badan Litbang dan Diklat Puslitbang Lektur dan Khazanah Keagamaan, 2011), $453 \mathrm{pp}$.

ISBN 978-602-8766-27-2

\title{
THE BOOK OF MANAQIB AND PROPHETIC HISTORY
}

\author{
Heddy Shri Ahimsa-Putra \\ Faculty of Cultural Sciences \\ Gadjah Mada University, Yogyakarta, Indonesia \\ ahimsa_putra@yahoo.com
}

\section{INTRODUCTION}

In order to understand to read the book completely with high curiosity, historians and scholars of socio-cultural studies need to be not only critical as usually required in every discipline, but also should be widely openminded and fully aware that history has diverse meanings in accordance with perspective used to interpret it. Why? This is because this book is an unusual book of history in usual sense of the words. Although written using historical sources or written documents about empirical events occured in the past, this book discusses the meaning of history and its sources started with doubting or questioning - indirectly_various assumptions underlying historical inquiries that have been conducted so far.

This book is basically a narration or a story about the Book of Manāqib that describes the legend of a famous Muslim scholar ('ulamā', sing. 'ālim) who was known among the Sufis as "Prince of Saints" (sultàn al-awliyā') or "pole of saints" (wali al-qutb), Shaykh "Abd al-Qadir alJilāni. Among Indonesian Muslims, he is popularly known as Syekh 'Abdul Qadir Jaelani., Of course, this book does not simply discuss the life of this legendary scholar, but also discusses the position and the significance of the Book of Manāqib of Shaykh "Abd al-Qadir al-Jilāni. The question remains, "what are the reasons leading Dr. Ajid to discuss such a book?" We can find the answer to this question throughout this book explicitly and implicitly.

\section{A. The Book of Manāqib of Shaykh 'Abd al-Qadīr al-Jīlānī} The first question we can raise is what does the author mean by the Book of Manāqib? Etimologicall, the word manāqib is plural form of the word manqaba, which is derivated from the word naqaba, meaning "a small hole 
through which one can see something behind." In Sufi tradition, this word is interpreted to mean "to see in extraordinary way the virtue of one's deed and his excellence, both according to his knowledge and deed." The word manāqib can also mean "a description of or a discussion of the severenity of a person who is able to enter a world which is difficult for one to enter." In other words, the word naqaba or nāqib can mean al-ärif bi shāhid al-qawm, that is "the wise person who was witnessed by people."1

Based on the above meanings, manăqib is defined by Ajid Tohir as "a kind of article or a figure's biography." However, it is more explanatory concerning various excellences or hospitalities happened to someone having "special" or "holy" values. Manāqib book is the writing containing such stories. Manāqib book is defined by Ajid Thohir as a "collection of systematic notes which explains about various excellences and hospitalities happened to someone having special values." Kitāb Manāqib of Shaykh 'Abd al-Qādir al-Jìiani (hereafter referred to as KMSA) is such a book that, with central figure of Shaykh 'Abd al-Qādir al-Jilāni, becomes the center of attention and the talk in the town. ${ }^{2}$

KMSA is a very important book for Muslims, who especially keep up with tradition and become members of Qädiriyah-Naqshbandiyah Sufi Order (tariqah). Qa diriyah is taken from the prime teacher's name, the central figure and the tariqah "founder," namely Shaykh "Abd al-Qādir alJilāni. Manāqib book, says Ajid Thohir, is a "hagiography" concerning someone's figure. In the group of religious persons, someone's figure is shown in various stories about intensity, grace (karāmah), piety, uniqueness, and smartness from the figure, which usually make them more and more obedient to keep up with his doctrines and advices.

In the group of a figure's adherents, like followers of Qādiriyah order, Manāqib book has become a historical writing form "giving very strong influence in building sectarian emotion, both in fiqh and Sufi tarīqah," said Ajid. In Islam, manāqib book "has had very popular position." KMSA has been shown up "in various versions and languages," and in Indonesia, the version of KMSA, which is in local language has also emerged. People who are interested in this book are not only the followers of Qādiriyyah order, but also "the majority of traditional Muslims in general." Even, more and more middle class people are recently starting to be interested in the book.

Shaykh 'Abd al-Qādir al-Jilāni is such an important figure that makes the manāqib book about him is published a lot, not only one. In the context of research conducted by Ajid here, the following question can be raised: which KMSA should be selected in order to be researched specially

\footnotetext{
${ }^{1}$ Ajid Thohir, Historisitas dan Signifikansi Kitāb Manāqib Syekh 'Abdul Qadir al-Jilani dalam Historiografi Islam (Jakarta: Badan Litbang dan Diklat, Kementrian Agama, 2011).

${ }^{2}$ Thohir, Historisitas dan Signifikansi.
} 
and extensively, to answer the proposed question? There are five books used by Ajid, those are (1) Bahjat al-Asrār wa-Ma'din al-Anwār of 'Ali bin Yūsuf al-Șatnūfí; (2) al-Rawḍ al-Z̄āhir fỉ Manāqib al-Shaykh 'Abd al-Qādir al-Jìiāi of Burhān al-Dīn al-Qadrī; (3) Qalā'id al-Jawāhir fì Manāqib alShaykh Tāj al-Awliyā' Shaykh Muhy al-Dīn 'Abd al-Qādir al-Jilāni, written by Muhammad bin Yahyā al-Tadafî al-Ḥanbali; (4) al-Lujayn al-Danī Manāqib Shaykh 'Abd al-Qādir al-Jilāni, written by 'Abd al-Karìm alBarzanī; (5) Tafrìkh al-Khätir fì Manāqib 'Abd al-Qādir al-Jilānì of Muhy al-Din al-Irbili. Of course, the selection of these books is done on basis of certain considerations, among others are: "paradigm and writing technique, structure and methodology, material and references, rhetoric and writing style, writer's intellectuality and capability as well as the other aspects." Unfortunately, the writing of titles of these books turns out not to be consistent, or the tradition of making the titles intentionally differs about 'Abd al-Qādir al-Jilāni's Manāqib. For example, the titles of the books which are on page 36 are not the same as the titles found in the other parts. ${ }^{4}$ So, we do not find out which title is correct or in line with the true one or the first published and, above all, the whole contents show creativity from the authors of manāqib book.

It is Ajid Thohir who researched those books, then compared one another in order to know the similarities and differences. There are many points compared; but, each point is not thoroughly discussed; the writer only compared the style of making the titles of manaqib/hagiography discussions. The results of comparison are discussed in table, so that the readers can easily know which book possesses the most factors which are considered important by researchers. The results show that Tafrikh alKhat irir has the most factors. Unfortunately, the table ${ }^{5}$ is obviously not easy to be read and interpreted, because manāqib factors written in the book are not strongly and consecutively compared to other manāqib factors. As a result, the similarities and differences among the books are not easy to be known by readers. The similarities among manāqib books appear especially in the part that tells about 'Abd al-Qādir al-Jilāni's birth and lineage, process of his studies, his students, and his friendliness.

The next question posed is "can the manāqib books be viewed as historical works, as defined in Western scientific tradition, or simply document which can be used as historical writing sources? If "yes", what reason can be proposed? If "not", what is the reason? And how sociocultural scientists or historians have to posit their works which not mostly makes up the books, the stories of which are close to Sufi stories in the context of Islamic history?"

\footnotetext{
${ }^{3}$ Thohir, Historisitas dan Signifikansi, 36

${ }^{4}$ Thohir, Historisitas dan Signifikansi, 258-269.

${ }^{5}$ Thohir, Historisitas dan Signifikansi, 272-281.
} 
The matter cannot be understood and answered through "conventional" viewpoint of science of history, as the contents of the manāqib/hagiography books contain many remarkable things; it is obvious that the position is so important either in tarekat or in Islamic people generally, specially, in Islamic historiography. Different viewpoints are necessary to be able to place various manăqib books in the context of "Islamic history." What kind of viewpoint? That is the thing that we need to know, and whether such a point of view can be accepted as the "scientific" viewpoint?

\section{B. Prophetic History}

The answer to this question depends on what the meaning of the "history" is. As it has already known, "history" is a concept or a term with certain meaning. From my analysis of the various contexts of the term "history," I found at least six meanings of "history." First, history can mean "the past", indicating "a period of time," as reflected in the statement "that was historical event," which means "that was the event which took place in the past." Second, history means "the events which happened in the past." The statement of "the event has been part of history," for example, has a meaning that the meant event has been part of the events taking place in the past." The phrase of "Indonesian history" is often defined as the events that happened in Indonesia last time ago. This event can be like changing processes, so that the history is always meant as "change process," or as inter-symptom interaction process, which has not definitely produced the changes. Third, history can also mean story "writings," "myth" concerning the events happening in the past. The phrase of "Indonesian history" is usually defined as the writings about or telling Indonesian situation in the past. Fourth, history means "the branch of science." This meaning appears clearly in historians' discussion and views. Here, history is called as a branch of science, especially the science which is "ideographical." This is the history as science taught in colleges. Fifth, history means "perspective" and "paradigm." The term of "historical perspective" is oftentimes used in socio-cultural scientists' discussions. Here, "history" is a viewpoint, point of view, and perspective. In other words, "history" is a paradigm used by scientists to understand the symptoms or events, both for nature, society, and for culture. Sixth, history means "program" or "department." We often hear the remark, "he is a historical student," or "I want to take up history first." History here is not a paradigm, science or story about an event, but "historical department." The history in the meaning of this "department" is more important administratively than theoretically. Nevertheless, history as

\footnotetext{
${ }^{6}$ Ahimsa-Putra, "Sejarah Baru?: Sejarah sebagai Ilmu dan Paradigma." A paper presented at national seminar at Gadjah Mada University (Yogyakarta, 2012).
} 
"department" remains important, as without infrastructure of a program or department, "history" as science and paradigm will not be able to branch out. ${ }^{7}$

In the context of the discussion, history is meant as writings, stories, and the stories about events happening in the past. Keeping up with historical writing tradition developed in West-which now is (the only one?) the view about history adhered by the world historians - the writings or criteria were usually written by historians who have taken education either in "historical science" or in socio-cultural science in a college. The criteria were written based on some information or facts which has been successfully collected from various sources (personal letters, journals, popular and scientific magazines, papers, report, books, governmental documents, and so on). The criteria are also regarded as the criteria the truth of which is able or proper to be reliable, until there are other criteria that point out the shortcoming and or mistake of the criteria themselves, and the truth is more reliable.

The next problem is in certain society, for example Moslem society, the criteria regarding the events in the past are not only written by historians as known today, but also written by individuals whose words are proper to be reliable. These criteria are not always about the events the truth which cannot be accepted both empirically and logically, since there are the stories regarding certain individuals' ability in them, especially religious people, holy people, to do certain deeds which cannot be done by ordinary people. The ability to do extraordinary deeds known as karämah, and usually can only be done by people "chosen by god" or prophet, it is not a strange thing in Moslem society.

In case the various stories regarding the holy people's karāmah are then accepted as "history" as known today, so the history makes no difference with myth and legend, which partly contains the stories about the extraordinary deeds having been done by certain individuals. Here, the historicity values of the books contain such stories, among other things KMSA, are questioned. So, how should we place the books like KMSA in the context of socio-cultural science, including historical science? There is no another way except by establishing a new historical paradigm, which differs from the existing historical paradigm, especially on the basic assumptions concerning socio-cultural reality and the truth.

This new historical paradigm I call "prophetic history", namely the branch of historical science which is one of the twigs of the prophetic socio-cultural science branch, while the prophetic socio-cultural science itself in one of the branches of the prophetic science, namely the science that receives an apocalypse, a constellation of apocalypses or holy books as

${ }^{7}$ Ahimsa-Putra, "Sejarah Baru?: Sejarah sebagai Ilmu dan Paradigma." 
one of knowledge sources. The thought about the prophetic science in Indonesia-as far as I know-at first is derived from Prof. Dr. Kuntowijoyo, professor of history at Faculty of Cultural Studies, Gadjah Mada University. The thoughts were written down in his book entitled Islam sebagai Ilmu: Epistemologi, Metodologi dan Etika, published in 2004. Nevertheless, his thoughts concerning the science have been spread earlier in his book entitled Paradigma Islam: Interpretasi untuk Aksi. ${ }^{8}$ What has been put forward by Kuntowijoyo is basically not at all the new thing in Islamic thoughts. We can find Islamic thinkers from his writings who influenced and gave him a lot of inspiration.

Kuntowijoyo wrote, that "the pedigree of his thoughts about the prophetic social sciences can be found in Muhammad Iqbal and Roger Garaudy's writings." Muhammad Iqbal is an Islamic thinker, while Roger Garaudy is a French philosopher converting to Islam. Kuntowijoyo took both thinkers' thoughts a lot to develop what he was expecting for as prophetic science, more specially, prophetic social science, as he is a historian as well as social scientist.

According to Kuntowijoyo, prophetic social science is transformative social science, "which does not only stop to explain social phenomena, but also to try to transform it." Kuntowijoyo proposed that to be prophetic social science, social science "does not only explain and change social phenomena, but also give some clues to where the transformation is done, for what and by whom it is done; therefore, the social prophetic science does not merely change for the sake of the change, but change based on certain ethical and prophetic aspiration."

The next question is "which are ethics, and which is prophetic?" As a Moslem, of course Kuntowijoyo then referred to at Islam. However, it is not the only reason. Other factors which are also important are that there are no other religions made the bases for our science today. The science we bequeath from society and Western life views is the science that has lost the spiritual spirit. ${ }^{10}$ Therefore, in his opinion, "we need to understand the holy Koran as paradigm"; and the paradigm meant by Kuntowijoyo is paradigm meant by Kuhn. He says, "In this understanding, the Koran paradigm means a knowledge construction that enables us to understand the reality like understand the holy Koran. The knowledge construction was the one firstly put forward by the holy Koran so that we have hikmah based on the bases, can form the behavior which accords with the Koran normative values, both on the moral level and the social level. However, the knowledge construction apparently also enables us to formulate a big

\footnotetext{
${ }^{8}$ Kuntowijoyo, Paradigma Islam: Interpretasi untuk Aksi (Bandung: Mizan, 1991).

${ }^{9}$ Kuntowijoyo, Islam sebagai Ilmu: Epistemologi, Metodologi dan Etika (Yogyakarta: Tiara Wacana, 2006),

${ }^{10}$ H. S. Ahimsa-Putra, "Paradigma Profetik: Mungkinkah? Perlukah?" A paper presented at national seminar at Gadjah Mada University (Yogyakarta: 2011).
} 
design concerning Islamic system, including the science system. Thus, in addition to giving axiological illustration, the Koran paradigm can also function to give epistemological insight...."11

Regarding that, Kuntowijoyo seems to agree with Roger Garaudy's view stating that Western philosophy (critical philosophy) "is not satisfying, as it only oscillates between two sides, idealism and materialism, without ending. The Western philosophy (critical philosophy) emerged from a question: how is the knowledge enabled. Garaudy suggested to change the question become: how is the apocalypse enabled.." ${ }^{2}$ Garaudy gave his opinion that "the Western philosophy has 'killed' god and human beings." Therefore, he suggested in order that the human race applies prophetic philosophy from Islam by recognizing the apocalypse."13 Of course, the recognition of the apocalypse is one of the bases or one of these knowledge sources will implicate philosophical assumptions concerning the knowledge itself.

The apocalypse is knowledge, which was possessed by the prophets from god, both directly and through his angels. Part of the contents is about the orders from god to human beings, the other parts are also like the stories about various events happening in the past, regarding the prophets as well as certain communities. Part of the apocalypse was then written and collected to become a holy book, then become principle and reference for acting, making decision, understanding and interpreting the life, as well as made as a charm.

The Holy Quran is one of the samples. In the holy Koran there are collected the prophets' stories, promises of Allah, the universe creator, to the religious people, threats of Allah for those who are faithless, certain communities' stories, prophets' prayers, the verses that can be the healers or can chase the devils away, and so on. Thus, in part of the holy Koran contents are actually the stories, stories about the certain communities and the important events gone through by some prophets. These stories are certainly history too. Even, for some Islamic adherents, it is more true history, more reliable than the history written by historians, as the contents of the holy book derive from god creating the mankind and the events itself. The history which is in the holy book makes up the most valid history, and the truth is the most reliable.

When the apocalypse which also makes up the history was considered to be and even made one of historical science sources, the whole basic foundations of historical science need to go through revision on a large scale, as there is no more explicit line which distinguishes between knowledge and science, as adhered so far. Philosophical assumptions which

\footnotetext{
${ }^{11}$ Kuntowijoyo, Islam sebagai Ilmu, 11

${ }^{12}$ Kuntowijoyo, Islam sebagai Ilmu, 97.

${ }^{13}$ Kuntowijoyo, Islam sebagai Ilmu, 98.
} 
are based on positivism philosophy are no longer enough to become the basis for history which recognizes the apocalypse as one of historical knowledge sources. Not only is it about that, but it is also about other philosophical genre-such as, phenomenology, hermeneutics, materialism, historism, post-modernism, are no longer able to made as the basis of new historical science, which encompass historical knowledge deriving from religion books. Philosophical science and new epistemology are necessary to be able to accept the view. This is the epistemology I call as prophetic epistemology, while the paradigms which show up in them are called prophetic paradigm.

Prophetic epistemology considers the apocalypse as one of the knowledge sources. This is the thing that differentiates the epistemology with another one in socio-cultural science. In this epistemology, the apocalypse believed derives from god, which basically has become part of humans' knowledge. In part of knowledge of this apocalypse there is the knowledge about various empirical symptoms existing and ever existed in humans' life, including various historical events in the past. For example, the story about prophet Musa a.s. in the Holy Quran is the historical story about the truth of which can be believed, as the knowledge derived from god, delivered to his prophets whose honesty is reliable. Part of the story is considered illogical to humans' thoughts today - for example, the story of Musa cleft the sea with his stick-, it does not mean that the whole story of Musa must be regarded as the story that never existed in real world in the past.

If the apocalypse can be made the basis of science, various holy books about holy people who are given certain karämah can also become the basis of science by themselves, especially socio-cultural science, such as archeology, anthropology, sociology, history, psychology, and so on. Historical truth of the book certainly must remain ensured by way of thorough research over the texts-like critical research over other historical sources-, accompanied by another empirical research. This position is also occupied by KMSA in prophetic historical context.

This is the prophetic epistemology and paradigm which actually exist behind Ajid Thohir's book writings. His historical science can be called prophetic history. Regarding that the prophetic epistemology and paradigm are not yet popular in Indonesia - some scientists at UGM and UII in Yogyakarta have now tried to develop them - so there will not be too astonishing if this book will later obtain sharp criticism from those who disagree with prophetic epistemological philosophical views. Nevertheless, there's nothing to worry about that. On the contrary, the criticisms need accepting generously and patiently, as it will be able to become input to reinforce the prophetic historical epistemological basis which has been built. 
In order to bring about useful scientific dialogue about this book between socio-cultural scientists and historians who have different epistemological view and paradigm with the scientist applying prophetic paradigm, it is necessary to have deeper presentation concerning theoretical and conceptual relationship between KSMA as the object and historical research source with prophetic historical paradigm.

\section{KMSA and Prophetic History}

The main question which emerges here is: can KMSA as a book containing stories about a famous shaykh in Islam be made as empirical historical writing source, as it is usually done in historian community? The answer is very clear: it can be. Can the book be called history too? Of course it can be. If so, how about karammah or stories about the Shaykh's abilities to do various things which are beyond ordinary humans' abilities, so that it is more similar to the "myth" than the real story? Can it become historical writing reference? Of course it can be. These answers need explaining any further.

First, history is basically criteria about the certain events, it is both about the pedigree, the socio-cultural background, various behavior and the deeds, and about the thoughts. Each a historical writing - as done by historians in general-always uses various kinds of information sources. The main thing is information source such as writings, documents, personal letters, journals, and reports. KMSA is included in category of this information source, that it contains various stories about Shaykh "Abd alQādir al-Jilāni's remarkable ability, it cannot make KMSA not become historical source. KMSA remains one of historical sources. Even, for Moslems, it is very important historical source. Let alone known that those who wrote KMSA are priests or very religious and knowledgeable people, whose words are proper to be believed for the truth.

Various stories about Shaykh 'Abd al-Qādir al-Jilānì's remarkable ability must even remain defended, because it can become data of two kinds of history. The first is about the shaykh, especially about his karamah. The collection about this karämah will certainly be able to become historical book, namely Shaykh 'Abd al-Qādir al-Jilānì's historical karāmah. Historians who are interested in these karämah phenomena could have regarded that the karamah is really possessed, various strange events deriving from the karamah also really happened in the past. He could then classified and arranged the sequence of kinds of the karamah based on periods in the shaykh's life. From here it will probably emerge a history about shaykh's karāmah, which tells about karāmah and various unique events started from childhood to shaykh's death. It is more likely that the story about karämah would seem to run coinciding with his teaching steps under some shaykhs' teaching at that time. Such historical story certainly 
has values which are more precious in comparison with the stories of heroes who died for a nation, for example, like General Sudirman's life history.

Second, the story concerning Islamic people's thought pattern at that time, especially regarding the thought about a shaykh, about what was considered important to a religious figure, as well as about his position in society, and also about their thoughts concerning their own "historical" writings. All this can be found out through interpreting method and inference (inference drawing) over the stories, which are in KMSA. By analyzing the way the priests or writers show Shaykh 'Abd al-Qādir alJilanī, it can find out the writers' views hidden behind the texts or the stories they wrote, the assumptions that they did not state about what was necessary to be shown from a religion figure, people's paragon, like Shaykh 'Abd al-Qādir al-Jilāni, the things that they ignored or intentionally they did not write about the shaykh's stories, and there are still many other aspects. In other words, not only can KMSA be positioned as one of historical writing sources, but it can also be the clues about historical writing pattern which applying or adhered by many writers or Islamic priests at that time. In this second position, KMSA can also become a sample of another pattern from historical writing or historiography.

Regarding the empirical truth status, some stories about karāmah in KMSA are certainly debatable. However, the debate about the thing basically will not bring a lot of advantages, remembering from certain point of view, the history can also be viewed as "myth," that is the criterion whose empirical truth is always questioned by those who believe in the truth of the myth. For example, Indonesian independence, according to most people's belief, it was obtained or started on August 17, 1945, when Mr. Karno and Mr. Hatta as president and vice-president of Indonesian republic, declared the Indonesian independence. Meanwhile, for Dutch people, Indonesian independence in de facto just happened when there was transfer of power from Dutch sides to Indonesian sides, after carrying out Round Table Conference (KMB), in December 1949. Therefore, Indonesian independence on August 17, 1945 is a myth for Dutch people, while for the Indonesians, the event is a historical reality, in which if it is not recognized by other sides will make the Indonesians offended.

Learning from the case, that is the Indonesians and Dutch people who have different view concerning the historical truth of Indonesian independence, we can say that historicity status of KMSA questioned by certain communities does not have to make KMSA lose the status, as this is still debatable too. However, such view will not accomplish the problem, as the root of problem is not identified and then discussed.

In the "preface" I will try to show that the doubt towards the historicity status of KMSA basically derives from certain epistemological view about history, science and knowledge. To be able to accept KMSA as 
work or historical writing source, it needs the different point of views, which I call prophetic paradigm. Paradigm recognizing the apocalypse from god as one of the science sources can itself recognize the stories about guardians' karamah as historical story or historical writing source, as history in this paradigm view is not more than the story about humans, society and their culture in the past whose empirical truth can always be questioned by anyone.

Accepting and recognizing the "history" (historicity) of KMSA will enable historians to get some advantages, which enable them to enrich the contents or Islamic historical substance as well as its historiography pattern. If the case can be agreed, the book written by Ajid automatically needs to be made reference book in historical science teaching at university level. Of course the academic agreement needs to be built over the basis of substantial thoughts, which can only emerge from critical dialogue concerning the contents of this book.

\section{CONCLUSION}

As far as I know, there have not been a lot of efforts done by Indonesian historians to try to dig and identify local historiographical patterns which still exist in ethnic groups or certain social groups, both in Indonesia and in other countries. One of the obstacles confronted here is scarcity of the local historiographical sources. In the obstacles which are difficult to face, Ajid Thohir has tried as much as he can not to give up. Supported with Arabic mastery, Ajid Thohir has managed to expose a historiographical patterns existing and being popular in Muslim society known as manāqib genre.

Of the historiographical points of view growing over the basis of Western philosophical thoughts, historiography having this manāqib genre is likely to be doubted for its historicity. However, in the post-modern world, in which a certain philosophical view has lost its ability to dominate the whole scientists' thoughts and society in general, as a matter of fact, manāqib genre needs wading into, researching, and learning seriously, as this genre can be an alternative in historiography and can bring quality progress of the humans' life itself.

In slowness, -if it is not the stagnation- new historiographical genre development in Indonesia, Dr. Ajid Thohir's efforts to show the historicity of an Islamic historiographical genre are like a glass of cool zam-zam water to kill the thirst, in the scarcity of scientific discussion on having good quality in Indonesia. 


\section{REFERENCES}

Ahimsa-Putra, H.S. "Paradigma Profetik: Mungkinkah? Perlukah?" Unpublished paper (2011).

-------. "Paradigma Profetik: Sebuah Konsepsi." Unpublished paper (2011).

-------.. "Sejarah Baru?: Sejarah sebagai Ilmu dan Paradigma." Unpublished paper (2012).

Anonymous. Laporan Penyelenggaraan Sarasehan Ilmu-ilmu Profetik.

Yogyakarta: Universitas Gadjah Mada, 2002.

Kuntowijoyo. Islam sebagai Ilmu: Epistemologi, Metodologi dan Etika.

Yogyakarta: Tiara Wacana, 2006.

-------. Paradigma Islam: Interpretasi untuk Aksi. Bandung: Mizan, 1991.

Thohir, A. Historisitas dan Signifikansi Kitab Manāqib Syekh 'Abdul Qadir al-Jilani dalam Historiografi Islam. Jakarta: Badan Litbang dan Diklat, Kementrian Agama, 2011. 